\section{EMBRYARIDDLE}

Aeronautical University

SCHOLARLY COMMONS
Journal of Aviation/Aerospace

Education \& Research

Volume 15

Number 3 JAAER Spring 2006

Article 8

Spring 2006

\title{
Influencing Factors in Degree Selection for Aviation Majors at Indiana State University
}

\author{
R. Troy Allen \\ troy.allen@indstate.edu
}

Kurt Barnhart

Follow this and additional works at: https://commons.erau.edu/jaaer

\section{Scholarly Commons Citation}

Allen, R. T., \& Barnhart, K. (2006). Influencing Factors in Degree Selection for Aviation Majors at Indiana State University. Journal of Aviation/Aerospace Education \& Research, 15(3). https://doi.org/10.15394/ jaaer.2006.1494

This Article is brought to you for free and open access by the Journals at Scholarly Commons. It has been accepted for inclusion in Journal of Aviation/Aerospace Education \& Research by an authorized administrator of Scholarly Commons. For more information, please contact commons@erau.edu. 


\title{
INFLUENCING FACTORS IN DEGREE SELECTION FOR AVIATION MAJORS AT INDIANA STATE UNIVERSITY
}

\author{
R. Troy Allen and R. Kurt Barnhart
}

\section{INTRODUCTION AND PROBLEM STATEMENT}

In many states the early years of this new century have brought new and varied challenges for higher education, the least of which is not ever-tightening institutional budgets. In this light it becomes prudent to utilize those resources we do have to their best and fullest extent. In many colleges and universities those resources are often allocated, to some extent, based on either a direct or indirect measure of student enrollments; numbers, for better or worse, are often king.

\section{PURPOSE}

The purpose of this study is to examine how to effectively manage recruiting resources of collegiate aviation programs by examining why an aviation degree was chosen. Put more simply, this study looked at the factors that influenced students to choose aviation as a college major. This study did not examine why students chose to attend Indiana State University (ISU) over another institution, thus, the results will be applicable to other institutions offering similar programs of study.

\section{LIMITATIONS/DELIMITATIONS}

This study is limited to a sample of just under onethird of the student population in ISU's Aerospace Technology Program. In addition, it was a self-reporting survey often requiring students to think back several years to some of the events on the survey. ISU is representative of an average to large sized collegiate aviation program located in the mid-west which and draws from other areas of the country giving the survey a more national representation. The self-report method is probably the most accurate method of data collection for this type of decision.

\section{INDIANA STATE UNIVERSITY}

Indiana State University is a comprehensive four-year undergraduate and doctoral degree granting institution located in Terre Haute Indiana. Total University on campus enrollment has hovered around 12,000 for several years. Colleges within the University include: The College of Arts and Sciences, The College of Education, The College of Business, The College of Health and Safety, The College of
Nursing, The College of Technology, and The College of Graduate Studies. The Aviation program, named "The Department of Aerospace Technology" is located within the College of Technology has four major degree programs: the two-year degree in Flight Technology (primarily consisting of distance education students), the four-year degree in Professional Pilot Technology, the four-year degree in Aviation Administration, and the dual Professional Pilot and Aviation Administration degree. Currently the department has just over 300 declared aviation majors (all students within the department declare an aviation major prior to taking classes) with approximately $80 \%$ pursuing either the Professional Pilot or the dual major degrees. The bulk of the remaining students are majoring in Aviation Administration with only $1-2$ percent choosing the 2-year degree. The department currently has six full-time faculty members, one department chair (time split between teaching and administration), four adjunct faculty, and two graduate assistants. Flight training is contracted through two independent flight contractors located at two nearby airports. All classroom activity is conducted on the main campus.

\section{IN THE LITERATURE}

A literature review was conducted for factors influencing the choice of a college major. Some of the subject terms searched for this review included:

1. Vocational Guidance

2. Occupational Aspiration 
3. Academic Aspiration

4. Career Choice

5. Socioeconomic influences

6. Educational Objectives

7. College Attendance

8. Student Educational Objectives

9. Student Recruitment

10. Higher Education Marketing

Writing for the Journal of College Admission, Richard Canterbury suggests that marketing in higher education is unique and different from private service sector marketing and that institutions cannot merely adopt methodologies from such entities. As such, it is thus incumbent upon us in aviation higher education to discover how our potential students are unique and how they are motivated to begin a career in aviation, something this study at least partially accomplished.

Robert Johnson echoes Canterbury's theme and suggests that what drives educational decision making is much more complex than previously thought. He suggests that attention to individual prospective students may be the key to successfully attracting students. As will be shown, our research bears witness to this fact and has implications for a more targeted one-on-one student experience.

Janice Dawson-Threat, and Mary Huba presented a paper at the 1996 annual meeting of the American Educational Research Association. Students from the College of Engineering (male-dominated) and the College of Education and Family and Consumer Sciences (femaledominated) at an unspecified institution were surveyed. This paper put forth among other findings that, in choosing a college major, over $72 \%$ of women and just over $67 \%$ of men made selections in areas which are traditionally dominated by their particular gender. It is no secret that aviation, specifically the operational side (pilots, mechanics, ATC controllers) is male-dominated. At ISU, this is also the case as approximately $12 \%$ of students are female.

Authors Randall and Jo Ann Bass recommend a highly pro-active approach to help influence students to choose a primary/secondary education-related major. They recommend education faculty go out of their way to recruit students by conducting special seminars and introductory courses aimed at prospective students and undecided majors on-campus. They also recommend that any department, college, or school (as appropriate) of education newsletters be made available to these prospective students and their families to help inform their selection process. They also recommended a more aggressive outreach program to primary and secondary schools.

In 1984 Tim Sanford and Paul Naylor reported on a study which surveyed 3,227 freshmen entering a large research-one public institution. They classified students according to their educational maturity. Educational maturity was linked to the degree of certainty regarding their selected major and choice of occupation. The more educationally mature, the more certain and visa versa. Interestingly, they found that the educationally mature students persisted (over four years) at a slightly lower rate than educationally immature students and visa versa. This study called for future research into the reasons behind this phenomenon.

In 1962 Barbara Jean Pickett of Colorado State University wrote an article regarding influencing factors in selecting a career in occupational therapy which indicated that $78 \%$ of initial interest in that field's students was generated via personal contact. Although a bit dated, this result is in keeping with our findings.

Marjorie Weishaar et. al. wrote in 1981 that the majority of students studied were significantly influenced by their father's occupation with respect to their own career field of choice.

Odell, Uzzell wrote similarly in 1961 that there is a significant relationship between a student's knowledge of a particular occupational model (person) and their own occupational aspirations.

\section{METHODOLOGY}

A convenience sampling consisted of whole classes at one time taking the survey on a voluntary basis. Institutional Research Board (IRB) approval was received prior to data collection (Appendix A). The classes represented a mix of all majors in ISU's aviation program with the exception of the two-year degree program students. The survey took five to seven minutes to complete and asked students to rate events or people on a scale from one to seven representing the amount of influence each event/person had on the choice of their college major (see appendix $B$ for instrument). There were sixteen items on the survey. There were a total of 95 respondents who participated in the study, 87 of which were males. Of the total respondents 38 had selected the professional pilot program, 19 were enrolled in the aerospace administration program and 38 listed that they were majoring in both. The age range of the respondent was $18-45$ years of age with a mean age of 22 years old. When reviewing the respondent's class standing 16 were freshman, 16 were sophomores, 29 were juniors and 34 were seniors. 


\section{RESULTS}

This research addresses some of the factors that motivate students to pursue a degree in aviation. Of the sixteen factors that were rated by the respondents, the three highest means were found in the following categories: flight in an aircraft $(M=5.71)$, visit to an airport $(M=4.92)$ and watching an aviation movie $(M=3.94)$. From this study it can be seen that for the sample taken there was more than one factor that typically influenced the respondent's decision to select a degree in aerospace. However, there are some factors that would seem to be more influential than others.

Table 1

Summary Statistics

Airshow Ed. Event $\quad$ Family M. Av. Pro. Counselor

'Mean (N=95)

$3.5 \quad 2.6$

3.9

3.7

1.6

1Standard Deviation

$2.1 \quad 2.0$

2.3

2.4 1.3

'Rounded to nearest $1 / 10$ 
Table 2

\section{$\underline{\text { Summary Statistics }}$}

Movie Visit Flight Teacher Faculty Friend

\section{${ }^{1}$ Mean N=95}

3.9

4.9

5.7

1.6

$2.0 \quad 2.8$

${ }^{1}$ Standard Deviation

$\begin{array}{lll}1.9 & 2.0 & 2.0\end{array}$

\begin{tabular}{lll}
1.3 & $1.7 \quad 2.3$ \\
\hline
\end{tabular}

'Rounded to nearest $1 / 10$

,

Table 3

\section{$\underline{\text { Summary Statistics }}$}

\begin{tabular}{lccccc}
\hline & Marketing & Military & Adv. & Parents & Other \\
\hline${ }^{1}$ Mean (N=95) & 1.7 & 2.5 & 2.1 & 3.4 & 1.9 \\
& 1.5 & 2.1 & 1.7 & 2.2 & 3.0 \\
'Standard Deviation & & & &
\end{tabular}


Key

AIRSHOW $=$ Air show that I attended

EDEVENT $=$ Aerospace education event that $I$ attended

FAMILYM = Other Family Member

AVPRO = Aviation Professional

COUNSEL $=$ Guidance Counselor

MOVIE = Movie

VISIT $=$ Visit to an airport

FLIGHT $=$ Flight in an aircraft

TEACHER = High school teacher

FACULTY $=$ Member of the aerospace faculty

FRIEND $=$ Friend

MARKET = University marketing

MILITARY = Visit to a military air base

$\mathrm{AD}=$ Other Advertisement

PARENTS $=$ Parents

OTHER $=$ If other what 


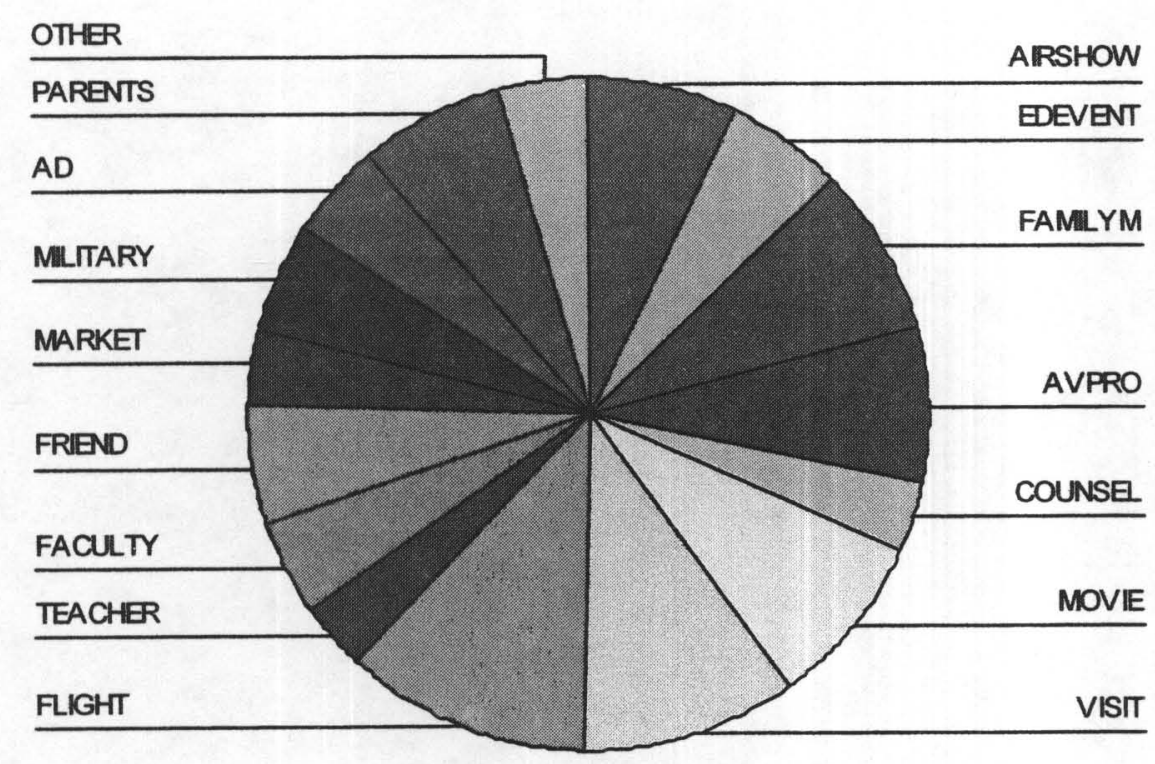

Figure 1. Breakdown of factors that influence the choice of aviation major 


\section{DISCUSSION, ANALYSIS, AND}

RECOMMENDATIONS

It is clear from the above depictions that the greatest influences on a decision to pursue a degree in aviation are those that are personal (one-on-one, with the possible exception of "movie") and aviation specific. Experience indicates that students who choose to major in aviation have a high degree of career focus going in to the college/university environment; in other words, they generally know what they want to do before they arrive. The top five influences are:

1. Flight in an aircraft

2. Visit to an airport

3. An aviation-related movie

4. A family member

5. An Aviation Professional

Notice that those influences that are not personal (marketing and advertising) or are likely not aviation specific (guidance counselor, high school teacher) are relatively un-influential. Thus, to be most effective, we need to be encouraging personal and aviation-specific activities where possible and rely less on means that are not individually targeted and, perhaps, general in nature. Aviation departments, colleges, and schools should prioritize personal contact activities with prospective students.

As a case in point, the Aerospace Technology Department at Indiana State Univeristy has had great success with enrolling prospective students by ensuring that, when possible, each student has at least one or two hours of personalized attention at the department level when they visit the department, usually from the chairperson. During this meeting, time is taken to get to know the student, their background and their career interests. After that, the aviation degree program of their choice is explained, questions are answered (or referred to the appropriate office), and an individualized tour of the facilities is given. Following this, many students will visit one, or both, of the two affiliated, but independent flight school contractors where they have additional personalized attention from those who will be conducting their flight training should flying be in their career plans. Undergraduate student enrollments within the aviation department continue to lead the College of Technology at Indiana State Univeristy, and, while individualized prospective student attention is not the only factor, it has been reported as being a key factor in the department's undergraduate enrollment success.

For those who may or may not be involved with the academic side of aviation but have opportunity to influence career choices for aviation outside of aviation, the advice from this study is simple; make time to take a young person to an airport and arrange a flight if possible. Allow them to ask questions and to even have some time on the flight controls if possible and appropriate. Many students have anecdotally reported that their interest was peaked by just such an activity. Seemingly small gestures such as these can, and does pay big dividends in the lives of many young people and, to the future of aviation as well.t

R. Troy Allen is beginning his fourth year with the Indiana State University (I.S.U.) Aerospace, Department. After graduating with a B.S. in Aviation Administration from ISU in 1989 he become employed by the Indiana Department of Transportation (INDOT) Aeronautics Section. While employed by INDOT he worked for four years as an airport inspector and another nine years as a project manager. He holds a private pilot certificate with instrument, sea and advanced ground instructor ratings. In 1999 he completed his M.A.S. degree at Embry-Riddle Aeronautical University and is presently completing the requirements for a Ph.D. in the Curriculum, Instruction and Media Technology Department in the College of Education at ISU.

R. Kurt Barahart is an assistant professor of aerospace technology at Indiana State University. He holds a commercial pilot certificate with instrument, multi-engine, seaplane and glider ratings. He also is a certified flight instructor with instrument and multi-engine ratings. In addition Dr. Barnhart holds an airframe and power plant license with inspection authorization. Dr. Barnhart holds an A.S. in Aviation Maintenance Technology from Vincennes University, a B.S. in aviation administration from Purdue University, an MBAA from Embry-Riddle Aeronautical University, and a Ph.D. in educational administration from Indiana State University. His work experience includes work as a flight instructor, A\&P mechanic, R\&D inspector with Rolls Royce Engine Company, and instructor for American Trans-Air airlines, and Embry-Riddle Aeronautical University. 


\section{REFERENCES}

Bass, R. V. (1990, 6, April). Strategies for Recruiting Education Majors in the 1990's. Presented at the Annual Meeting of the Arkansas Association of Colleges for Teacher Education, Little Rock, AR.

Canterbury, R. (1999, Fall). Higher Education Marketing: A Challenge. Journal of College Admission, 165, 22-30.

Dawson, J. (1996, 8-13, April). Choice of Major and Clarity of Purpose Among College Seniors. Presented at the Annual Meeting of the American Educational Research Association, New York, NY.

Johnson, R. E. (1998, Spring). Where Consumer has Become King. Trusteeship, 6(2), 26-29.

Pickett, B. J. (1962). Factors Influencing Choice of Occupational Therapy as a Career Choice: Implications for Recruitment of Students. American Journal of Occupational Therapy, 16(2), 84-88.

Uzzell, O. (1961). Influencers of Occupational Choice. Personnel \& Guidance Journal, 39, 666-669.

Weishaar, M. E. (1981). Primary Influencers of Vocational Choices for College Women. Journal of Vocational Behavior, 18(1), 67-78. 